\title{
Hakikat Hukum Ekonomi (Internasional) Dalam Perspektif Teori Keadilan Bermartabat
}

\author{
Jeferson Kameo dan Teguh Prasetyo \\ Fakultas Hukum Universitas Kristen Satiya Wacana Salatiga \\ dan Fakultas Hukum Universitas Pelita Harapan Jakarta \\ Jln. Diponegoro No. 52-60 Salatiga \\ jeferson.kameo@staff.uksw.edu dan teguh.prasetyo@uph.edu
}

Received: 2 Januari 2020; Accepted: 15 Juni 2020; Published: 25 Agustus 2020

DOI: $10.20885 /$ iustum.vol27.iss2.art5

\begin{abstract}
The legal issue that is raised and examined in this article is the concern that has recently emerged behind the development of (international) economic law. As if the (international) economic law would threaten the sovereignty of countries. This type of research is normative legal research. The results of the research and discussion conclude that the anxiety over such (international) economic law developments is excessive. Even though it is necessary to make efforts as a sign of caution. It is proven that in (international) economic law does not override national law. The theory of dignified as a pure legal theory becomes a tool kit to describe at a glance the "face" of (international) economic law that should not be worried about. Each sovereign state must give consent before the rules and legal principles are applied and enforced within and among the countries that are binding themselves in a form of international agreement. It is at this stage of the approval that the filter with legal values in the soul of the nation (Nolksgeist) that safeguards the sovereignty of a nation and state can be used to select (international) economic law.
\end{abstract}

Key Words: Economic law; theory of dignified justice; Pancasila

\section{Abstrak}

Isu hukum yang diangkat dan dikaji dalam artikel ini, adalah adanya kecemasan yang akhir-akhir ini muncul di balik berkembangnya hukum ekonomi (internasional). Seolah-olah hukum ekonomi (internasional) akan mengancam kedaulatan negara-negara. Jenis penelitian yang digunakan adalah penelitian hukum normatif. Hasil penelitian dan pembahasan menyimpulkan bahwa kecemasan di baik perkembangan hukum ekonomi (internasional) seperti itu berlebihan. Sekalipun usaha-usaha sebagai tanda kewaspadaan perlu dilakukan. Terbukti bahwa dalam hukum ekonomi (internasional) tidak mengesampingkan hukum nasional. Teori keadilan bermartabat (the dignified justice theory) sebagai teori hukum murni menjadi tool kit untuk menggambarkan selintas "wajah" hukum ekonomi (Internasional) yang tidak harus dicemaskan tersebut. Setiap negara berdaulat itu harus memberikan persetujuan sebelum kaidah-kaidah dan asas-asas hukum itu diaplikasikan dan ditegakkan di dalam dan diantara negara-negara yang mengikatkan diri dalam suatu bentuk kesepakatan internasional. Pada tahapan pemberian persetujuan itulah saringan dengan nilai-nilai hukum di dalam jiwa bangsa (Volksgeist) yang menjaga kedaulatan suatu bangsa dan negara dapat dipergunakankan menyeleksi hukum ekonomi (internasional).

Kata-kata Kunci: Hukum ekonomi; teori keadilan bermartabat; Pancasila 


\section{Pendahuluan}

Tulisan ini disusun untuk menggambarkan dan menjelaskan secara singkat usaha mengatasi kecemasan di balik perkembangan Hukum Ekonomi (Internasional). ${ }^{1}$ Diharapkan melalui tulisan ini juga tergambarkan suatu pemahaman yang kritis mengenai hakikat (the nature) atau sisi ontologis pengaturan dalam Hukum Ekonomi (Internasional) beserta ruang lingkup dari bidang hukum yang relatif baru itu. Perspektif Teori Keadilan Bermartabat ${ }^{2}$ digunakan sebagai tool kit untuk menggambarkan seketsa "wajah", profil singkat atau hakikat Hukum Ekonomi (Internasional). Perspektif teori dimaksud adalah suatu perspektif baru Ilmu Hukum Indonesia (the Indonesian Jurisprudence) yang dibangun dan dikembangkan di Indonesia dan belum pernah digunakan untuk tujuan seperti dikemukakan di atas.

Apa yang disebut sebagai hukum ekonomi itu, merupakan suatu cabang ${ }^{3}$ dari hukum. Dikatakan merupakan cabang, karena hukum ekonomi tumbuh dari tradisi dalam hukum perdata murni, hukum dagang (Commercial Law), lalu bercampur dengan hukum pidana modern. ${ }^{4}$ Menurut para penulis, hukum ekonomi adalah hukum administrasi negara (Administrative Law) dan berbagai cabang hukum lainnya dalam ilmu hukum, merespons kebutuhan pengaturan

${ }^{1}$ Tanda kurung diberikan pada kata internasional, karena pada prinsipnya ada titik temu antara hukum ekonomi dan hukum ekonomi internasional. Kata internasional, hanya memberi sifat saja pada Hukum Ekonomi. Penambahan kata internasional, sekedar untuk membedakan dengan hukum ekonomi nasional. Frasa Hukum Ekonomi Nasional itu sesungguhnya tidak ada, yang ada hanya Hukum Ekonomi.

${ }^{2}$ Untuk memahami dengan lebih baik mengenai teori keadilan bermartabat, lihat Teguh Prasetyo; Keadilan Bermartabat: Perspektif Teori Hukum, Cetakan Pertama, Nusamedia, Bandung, 2015. Banyak publikasi internasional bereputasi yang telah menjadikan teori keadilan bermartabat menjadi ilmu hukum yang go internasional; antara lain: TeguhPrasetyo, "Pancasila the Ultimate of All the Sources of Laws (A Dignified Justice Perspective)", Journal of Law, Policy and Globalization, International Institute for Science, Technology and Education (IISTE), Vol. 54, October 2016; Criminal Liability of Doctor in Indonesia (From A Dignified Justice Perspective), International Journal of Advanced Research (IJAR), Vol. 1, No. 10; TeguhPrasetyo and Tri AstutiHandayani.,Legal Aid Principle: (Dignified Justice Theory Perspective),International Journal of Advanced Research (IJAR), Vol. 1 No. 10, 2016; Shallman, Teguh Prasetyo and Amin Purnawan, Public Service on Land Registration Based on the Dignified Justice, Journal of Advanced Research (IJAR), Int. J. Adv. Res.5(5), 154-163, 1016. Pada bulan Juli 2017 penggagas Teori Keadilan Bermartabat, Teguh Prasetyo mempresentasikan Teori Keadilan Bermartabat di Belanda, Vrije Universiteit Amsterdam dan di hadapan Dekan Vrije Universiteit Amsterdam serta dua professor di bidang hukum, mahasiswa magister dan Ph.D.

${ }^{3}$ Analogi cabang dari botanika ini membawa orang kepada suatu pemahaman bahwa pasti ada Pohon yang mengelurkan cabang dan selanjutnya dari cabang itu keluar lagi ranting.

"I Gusti Ayu Ketut Rachmi Handayani, dkk., "The Application of Article 359 of the Criminal Code in the Investigation of the Death of Post-Operative Patients", Asers Publishing, Vol VIII, Issue 5, September 2017, p. 27. 
(regulatory needs) dari gerakan dan konsep negara kesejahteraan (the welfare states) dan juga perekonomian campuran setelah Perang Dunia Ke-II (PD-II).

Masih ada pula cabang lain yang berpengaruh dalam keterbentukan hukum ekonomi (internasional), yaitu hukum yang mengatur mengenai hak-hak asasi manusia (human rights) dan hukum tata negara (Constitutional Law). Sudah menjadi pengetahuan umum bahwa dua bidang hukum terakhir ini mendominasi tatanan hukum setelah PD-II. Atas dasar itu, Hukum Ekonomi (Internasional) diidentikan dengan kebendaan milik publik yang paling penting dan bernilai tinggi. Dari padanya, hak-hak asasi manusia, kesejahteraan dan kemakmuran dari miliaran manusia secara kritis bergantung; sama dengan pohonya yang kuat, dalam postulat teori keadilan bermartabat, Hukum Ekonomi (Internasional) sebagai cabang hukum juga berprinsip bahwa Hukum adalah sumber kebahagiaan (the Law as a source of happiness). ${ }^{5}$

Secara umum, hukum ekonomi memberikan pembatasan-pembatasan dan merumuskan definisi-definisi dari ruang lingkup kesempatan-kesempatan bagi manusia individual dan keadilan distributif dalam suatu masyarakat. Lapangan hukum yang disebut dengan Hukum Ekonomi itu meliputi begitu luasnya pokokpokok bahasan. Ada bertimbun-timbun, atau rimba raya kaidah dan asas hukum. Seperti misalnya, kaidah dan asas-asas hukum tentang perusahaan, berbagai macam transaksi bisnis dan perdagangan, perpajakan, persaingan usaha, pengadaan barang dan jasa Pemerintah, penanaman modal asing maupun domestik, hak-hak atas kekayaan intelektual, pengaturan tentang perdagangan dan pembiayaan, sistem penjaminan dan hukum keuangan, perlindungan atas kesehatan, lingkungan hidup dan ketenagakerjaan serta hubungan industrial dan lain sebagainya. Semua kaidah tersebut, baik yang bersifat konvensional maupun elektronik (cyber); masih tercerai-berai, lalu diupayakan sistimatisasi menjadi suatu cabang hukum, yaitu hukum ekonomi ${ }^{6}$. Belum dapat ditunjukkan apakah suatu aspek tertentu, misalnya hak-hak atas kekayaan intelektual sebagai suatu pokok bahasan dari hukum ekonomi. 46.

${ }^{5}$ Teguh Prasetyo, Keadilan Bermartabat Pespektif Teori Hukum, Cetakan I, Nusa Media, Bandung, 2015, hlm.

${ }^{6}$ Abby Kadar, Ken Houle \& Geoffrey Whitehead, Business Law, $4^{\text {th }}$ Edition, Butterworth-Heinemann Ltd., Oxford, 1996, hlm. 4. 
Untuk sementara ini, himpunan kaidah dan asas-asas hukum sebagaimana disebutkan di atas tersebut, mengatur berbagai macam subyek hukum, atau pelaku. Ada yang merupakan perusahaan, produsen, konsumen, pekerja dan buruh, juga warga negara dan lain-lain. Secara horisontal, hukum ekonomi yang ruang lingkupnya telah dikemukakan di atas tersebut, memengaruhi dan bahkan diakui eksistensinya oleh mereka yang sebelumnya berada dalam ruang yang secara klasik telah terpisahkan menjadi publik dan privat. Bidang-bidang hukum perdata yang inti, misalnya hukum perjanjian dan hukum yang mengatur mengenai perbuatan melawan hukum ditemukan merupakan elemen-elemen kunci bagi Hukum Ekonomi (Internasional), sekalipun hingga saat ini tidak ada yang memastikan bahwa hukum perjanjian misalnya, dapat disebut sebagai hukum ekonomi.

Hukum Tata Negara dan Hukum Administrasi Negara, keduanya juga dapat dikatakan sangat signifikan berkontribusi secara berarti dalam keterbentukan dan beroperasinya Hukum Ekonomi (Internasional). Pendidikan dan Pelayanan Kesehatan, dan itu berarti merupakan wilayah-wilayah urusan Pemerintahan dan aktivitas yang sejenis atau yang mirip atau bahkan sama dan sebangun dengan urusan organ kenegaraan (para-statal activities) di kebanyakan negara di muka bumi ini, merupakan persyaratan yang esensialia bagi berhasilnya pembentukan Hukum Ekonomi (Internasional).

Sebagaimana sudah umum dipahami, bahwa hampir semua lapangan hukum, termasuk Hukum Pidana klasik (Penal Law), memiliki relevansi dengan hubungan ekonomi (economic relations). ${ }^{7}$ Secara vertikal, hukum ekonomi itu justru berisi segala macam regulasi yang mengatur di semua strata Pemerintahan: baik itu di aras lokal, nasional, regional maupun internasional. Sebagai cabang dari hukum, hukum ekonomi ikut menikmati karakter hukum dan dikatakan berada di depan. Ia memimpin globalisasi hukum menurut hukum, begitu pula dalam melakukan regionalisasi dari hukum; walau pada prinsipnya pusat dari seluruh pergerakan itu berada dalam kehendak masing-masing negara bangsa berdaulat.

Berkaitan dengan apa yang dikemukakan di atas, Roy Goode mengatakan bahwa hukum Masyarakat Eropa (European Community law) untuk pertama 
kalinya dan yang paling penting telah melahirkan Hukum Ekonomi (Internasional). ${ }^{8}$ Hampir semua bidang dari hukum ekonomi domestik di Uni Eropa dapat dicari hubungannya yang parsial dalam European Community Law, atau hukum ekonomi (internasional).

Hanya saja, semua bidang hukum ekonomi di Uni Eropa, atau European Community law saat ini merupakan loloh-balik dari masukan hukum nasional dan koreksi bagi pembenahan atau pembaharuan hukum ${ }^{9}$ di tataran domestik. Sebaliknya, Britania Raya bereaksi, dengan hukum nasionalnya menolak European Community Law dengan kebijakan "Brexit" (British Exit).

Hukum Perdagangan Internasional, yang sudah menjadi klasik, begitu pula dengan hukum dagang dengan nama yang lebih klasik lagi yaitu lex marcatoria, mulai mendapat "baju baru" (lex mercatoria novum), yaitu Hukum Ekonomi (Internasional). Meskipun begitu lama dipandang sebagai marginal, namun apa yang disebut dengan Hukum Ekonomi (Internasional) itu, kini, telah bergerak ke tengah. Hal itu terjadi di seluruh dunia, termasuk Indonesia ditandai, antara lain, kemunculan dan penerimaan the World Trade Organization (WTO) memberi tuntunan dan menjaga serta mengendalikan globalisasi perdagangan dunia. ${ }^{10}$

Atas dasar itu maka dapat dikatakan, bahwa hukum ekonomi (internasional) telah menjadi suatu fenomena yang kompleks. hukum ekonomi (internasional) terdiri dari berbagai macam asas atau prinsip-prinsip hukum, kaidah-kaidah hukum, serta berbagai macam pengaturan yang berurusan dengan substansi hukum, begitu pula prosedur. Dalam artiyang luas, hukum ekonomi (internasional)mengatur produksi, perdagangan dan konsumsi barang-barang dan jasa, baik itu domestik maupun internasional. Untuk itu, hukum ekonomi (internasional) menggunakan pendekatan regulasi atau pengaturan yang luas.

Artikel ini merupakan hasi penelitian ${ }^{11}$ hukum ekonomi (internasional) yang bermaksud untuk menggambarkan secara utuh "wajah" atau profil dari hukum ekonomi (internasional). Apa yang diungkapkan dalam tulisan ini hanyalah sebagian kecil "wajah" persoalan struktural dalam hukum ekonomi

${ }^{8}$ Roy Goode, Commercial Law, New Edition, Penguin Books, England, 1995, hlm. 1210.

${ }^{9}$ Teguh Prasetyo, Pembaharuan Hukum: Perspektif Teori Keadilan Bermartabat, Cetakan Pertama, Setara Press, Malang, 2017, hlm. 3.

${ }^{10}$ Ibid.

${ }^{11}$ Penelitian Hukum: Suatu Perspektif Teori Keadilan Bermartabat, Cetakan ke-1, Nusa Media, Bandung, 2019. 
(internasional) saja, yaitu soal-soal berkaitan dengan penilaian atas akibat-akibat yang ditimbulkannya bagi demokrasi, kedaulatan di tangan rakyat dan kedaulatan negara serta identitas masyarakat tempat manusia sebagai makhluk ciptaan Tuhan Yang Maha Esa yang mulia itu berada.

Struktur dari penulisan ini terdiri dari: pendahuluan, seperti telah dikemukakan di atas. Selanjutnya, merupakan pembahasan dari gambarkan pertentangan yang terjadi dalam persaingan bidang harmonisasi dan pengaturan. Berkaitan dengan itu dikemukakan fungsi konstitusional dari hukum ekonomi (internasional).

Dalam rangka menjawab rumusan permasalahan dan tujuan penelitian, dipaparkan sebagai hasil penelitian dan pembahasan tentang berbagai akibat dan implikasi prinsip-prinsip dasariah mengenai non-diskriminasi terhadap struktur Pemerintahan seperti misalnya terhadap Kedaulatan Negara. Tulisan ini ditutup dengan suatu kesimpulan dan pandangan tentang tantangan-tantangan hukum ekonomi (internasional) di masa depan yang harus dijawab.

\section{RumusanMasalah}

Adapun rumusan masalah dari penelitian ini, yaitu bagaimana "wajah" atau hakikat dari hukum ekonomi (internasional) perspektif teori Keadilan Bermartabat?

\section{TujuanPenelitian}

Tujuan dari penelitian ini, yaitu menggambarkan dan menemukan suatu profil atau "wajah" serta hakikat dari hukum ekonomi (internasional) dalam perspektif teori Keadilan Bermartabat

\section{MetodePenelitian}

Metode yang dipergunakan dalam penelitian ini, yaitu metode penelitian hukum normatif. Sejalan dengan pemikiran teori Keadilan Bermartabat sebagai suatu teori hukum murni (the pure theory of law) ${ }^{12}$ yang sui generis. Teori ini memiliki suatu variabel, atau postulat bahwa hukum hanya dapat ditemukan dalam jiwa bangsa (Volkgeist). Sekalipun nampak seolah-olah hukum itu berasal

${ }^{12}$ Teguh Prasetyo, Pembaharuan Hukum Perspektif Teori Keadilan Bermartabat ...., Op. Cit., hlm., 4. 
dari luar, namun ubi societas ibi ius, hukum itu ada di mana-mana, di mana ada masyarakat di situ ada hukum dan dapat dicari dan digali dalam jiwa bangsa. Penelitian ini menggunakan pendekatan perundang-undangan (statute approach). Peraturan perundang-undangan, baik di tingkat nasional dan internasional yang menjadi satuan amatan utama dilihat sebagai manifestasi empiris yang dapat diamati dari jiwa bangsa. Analisis dilakukan secara deskriptif-kualitatif.

Substansi Peraturan perundang-undangan, terutama yang meratifikasi Konvensi WTO yang di-survey dalam penelitian dan penulisan ini sebagai bahan hukum primer; yaitu Undang-Undang Republik Indonesia Nomor 7 Tahun 1994 tentang Pengesahan Agreement Establishing the World Trade Organization (Persetujuan Pembentukan Organisasi Perdagangan Dunia) menjadi tumpuan utama amatan dan analisis; disamping itu sedapat mungkin, sejauh memiliki relevansi diamati pula peraturan perundangan lainnya yang berkaitan dengan WTO, seperti misalnya, Undang-Undang Republik Indonesia Nomor 24 Tahun 2000 tentang Perjanjian Internasional menjadi satuan amatan penting yang dapat memberikan gambaran singkat tentang "wajah" hukum ekonomi (internasional) diharapkan tergambarkan.

\section{Hasil Penelitian dan Pembahasan}

Menjawab rumusan permasalahan di atas, yaitu bagaimana hukum ekonomi (internasional) dalam perspektif teori keadilan bermartabat, para penulis perlu dahului pembahasan di bawah ini dengan suatu gambaran singkat mengenai pisau analisis yang disebut dengan teori, jurisprudence keadilan bermartabat tersebut. Teori ini sudah umum dikenal dengan the Indonesian Jurisprudence. Teori hukum yang dipergunakan dalam menavigasi penelitian dan penulisan ini, sering kali disingkat dengan keadilan bermartabat (dignified justice).

Teori itu dibangun atas kesadaran seorang jurist Indonesia untuk membentuk suatu Indonesian Jurisprudence. Teori keadilan bermartabat, adalah suatu teori hukum murni (the pure theory of law). Dikatakan murni, karena teori ini memperhatikan nilai-nilai hukum yang dirumuskan dalam hukum positif yang berlaku dalam suatu jurisdiksi berdaulat. Teori itu berpendirian, antara lain, 
bahwa hukum itu selalu berisi keadilan ${ }^{13}$ dalam jiwa bangsa (Volksgeist); namun, bukan sembarang keadilan tetapi keadilan yang bermartabat.

Disebut dengan perspektif keadilan bermartabat, mengingat keadilan yang dimaksud bukan keadilan Plato, atau keadilan ala Aristoteles, maupun keadilan versi John Rawls, atau keadilan menurut hukum, maupun teori hukum Barat. ${ }^{14}$ Di Indonesia basis keadilan, adalah keadilan bermartabat. Keadilan harus diberikan adjective "bermartabat", karena keadilan itu dibangun di atas Pancasila sebagai perjanjian atau kesepakatan pertama bangsa indonesia. ${ }^{15}$ Meskipun demikian, teori keadilan bermartabat tetap memanfaatkan sumber-sumber pembanding (comparative laws analysis), misalnya berbagai literatur yang dapat dilihat dirujuk dalam tulisan ini. Keadilan bermartabat itu adalah keadilan yang memanusiakan manusia (nguwongke uwong) menurut hukum dan peraturan perundangundangan yang berlaku. Keadilan Bermartabat berpostulat bahwa hukum adalah sumber keadilan yang bermartabat, yaitu keadilan yang memanusiakan manusia.

Dikatakan hukum memanusiakan manusia karena dalam perspektif teori Keadilan Bermartabat itu, manusia di dalam masyarakat dilihat sebagai makhluk ciptaan Tuhan Yang Maha Esa yang mulia. Keberadaan hukum, termasuk hukum ekonomi (internasional) bertujuan, tidak lain, yaitu untuk memanusiakan manusia, menjaga keutuhan makhluk ciptaan Tuhan yang Maha Esa yang mulia itu di dalam masyarakat (baik masyarakat internasional maupun domestik).

Jika dikatakan bahwa di dalam hukum, keadilan harus bermartabat, maka orang akan berpikir bahwa sudah barang tentu ada keadilan yang tidak bermartabat. Pemikiran seperti itu, benar adanya. Dalam kenyataannya, ada keadilan yang dibangun di luar hukum, misalnya keadilan berbasis ideologi

\footnotetext{
${ }^{13}$ Hukum itu sumber kebahagiaan (the law is the source of hapiness); tidak ada harta dan benda, property atau kekayaan, maupun hikmat apa pun yang dapat memberikan kebahagiaan kepada manusia, makhluk ciptaan Tuhan Yang Maha Esa yang mulia selain hukum (the Law). Dengan mematuhi hukum yang berlaku, baik di aras Nasional maupun Internasional, termasuk hukum ekonomi (internasional) niscaya manusia di dalam masyarakat otomatis menjadi bahagia, dimanusiakan (di-unongke). Kebahagiaan dan kekayaan itu hanya konsekuensi logis saja dari mematuhi hukum yang berlaku. Di Indonesia, dalam benak para jurists Indonesia hukum itu adalah perjanjian pertama, yaitu Pancasila, Pancasila menjadi sumber dari segala sumber hukum.

${ }^{14}$ Sudah banyak dikupas dan diikuti pikiran keadilan Barat, satu yang paling mutakhir akhir-akhir ini, yaitu keadilan yang dirumuskan John Rawls. Lihat John Rawls, A Theory of Justice (Revised Edition), Harvard University Press, USA, 1999.

${ }^{15}$ Tentang Pancasila sebagai Kesepakatan Pertama, lihat Teguh Prasetyo dan Abdul Halim Barkatullah, Filsafat, Teori, \& Ilmu Hukum: Pemikiran Menuju Masyarakat yang Berkeadilan dan Bermartabat, Cetakan I, RajaGrafindo Persada, Depok, 2012, hlm. 367.
} 
(Kapitalisme, Marxisme dan lain sebagainnya); selalu, inherent ideologi itu melahirkan dan menjadi akar konflik antara sesama manusia dan dengan demikian menjadi tindak bermartabat; manusia makhluk ciptaan Tuhan Yang Maha Esa yang mulia selalu merasa cemas dan tidak nyaman dalam keadilan di luar hukum.

Banyak sekali, hampir setiap kali menghela nafasnya, manusia menyaksikan dalam kehidupan dan sejarah, ia berhadapan dengan keadilan yang tidak memanusiakan manusia. Gambaran umum tentang keadilan yang tidak memanusiakan manusia, boleh jadi terlihat dalam hukum ekonomi (internasional). Secara abstrak, Thomas Hobbes misalnya menggambarkan situasi itu dengan homo homini lupus yang melahirkan kecemasan. Berbeda dengan perspektif teori keadilan bermartabat, hukum ekonomi (internasional) menurut keadilan bermartabat eksis untuk merombak struktur pemikiran Hobbes dan memberikan kepastian bahwa sesungguhnya ada keadilan yang memanusiakan manusia ${ }^{16}$.

\section{Prinsip Persaingan Pengaturan versus Harmonisasi}

Negara bangsa di mana pun dibangun di atas dasar gagasan melakukan harmonisasi hukum. Dalam Pancasila, merujuk pada perspektif keadilan bermartabat yang menjiwai konstitusi Indonesia, dan selanjutnya mendikte seluruh peraturan perundang-undangan di bawahnya di dalam sistem hukum Pancasila, antara lain hukum ekonomi (internasional) seperti WTO misalnya, perangai itu ditandai oleh fraseologi: "...menciptakan perdamaian abadi" dalam konstitusi. Dalam harmonisasi diciptakan dan dipelihara persyaratan yang sama bagi semua pelaku usaha untuk berkompetisi. Hanya saja, dalam melakukan hal itu tetap diakui bahwa secara internasional negara-negara bangsa umumnya bekerja di atas dasar doktrin hukum persaingan pengaturan (the doctrine of regulatory competition). Prinsip ini secara diametral, menurut penulis berhadaphadapan (versus) dengan prinsip harmonisasi, yang melahirkan kecemasan.

Dalam prinsip kompetisi, negara-negara bangsa membatasi syarat-syarat kompetisi bagi para pelaku usaha mereka (operators) supaya bersesuaian dengan

${ }^{16}$ Teguh Prasetyo, Keadilan Bermartabat Perspektif Teori Hukum...., Op. Cit., hlm. 105, 124. 
syarat-syarat dalam pasar domestik maupun eksport. Mereka memberikan perlindungan kepada industri-industri domestik masing-masing. Mereka juga melindungi konsumen dalam negara mereka masing-masing. Dalam persaingan perdagangan, mereka mengikutkan para produsen mereka sendiri, dengan maksud menguntungkan konsumen, bersaing dengan produsen asing.

Akibatnya, muncul berbagai bentuk peraturan (regulatory) yang memiliki ciri-ciri sentralisasi dan harmonisasi di tingkat Pusat, hasil dikte internasional dan meninggalkan prinsip-prinsip demokrasi dan kedaulatan negara. Aturan-aturan anti kompetisi yang terdesentralisasi disesuaikan dengan aturan-aturan pemerintah pusat. Ambil contoh, Hukum Masyarakat Ekonomi Eropa (EC-Law). Struktur dari EC-Law itu sesungguhnya mengikuti logika atau jalan berpikir prinsip kompetisi pengaturan domestik. Selain konpetisi pengaturan ada pula harmonisasi hukum. ${ }^{17}$

Menelusuri lebih dalam, dalam prinsip harmonisasi, ternyata prinsipprinsip kemerdekaan dan kebebasan diutamakan dalam perdagangan domestik, diskriminasi diperangi, pengendalian yang sangat berlebih-lebihan dengan maksud untuk melayani proteksionisme daerah tertentu dicegah. Di tingkat global hukum WTO (the WTO Law) menggunakan pola yang sama. Hukum WTO secara parsial telah melakukan harmonisasi hukum. Di aras internasional perjanjian perjanjian saling kesepahaman biasanya dicapai baik dengan basis regional atau bilateral. Sejak Uruguay Round, WTO telah berkembang pendekatanpendekatan dasar yang bersifat integrasi positif. Misalnya dalam hal perjanjian mengenai aspek-aspek perdagangan dari hak-hak atas kekayaan intelektual \{The Agreement on Trade-Related Aspects of Intellectual Property Rights (TRIPs)\}.

Para ahli hukum perbandingan (the traditions of comparative law), memainkan peranan yang penting, dan tidak terhindarkan dipergunakan untuk menjelaskan akan hal ini. ${ }^{18}$ Wajah hukum ekonomi (internasional) tidak terlepas dari wajah comparative law. Dalam pada itu, para ahli hukum perbandingan mengambil contoh Swis. Mengamati Swis dalam perspektif perbandingan hukum, yang tidak

\footnotetext{
${ }^{17}$ Roy Goode, Commercial Law..., Loc. Cit.

${ }^{18}$ Dengan pemaparan yang demikian itu maka Hukum Ekonomi (internasional) dalam perspektif keadilan bermartabat itu, juga tidak dapat dilepaskan dari comparative law.
} 
dapat dipisahkan dari hukum ekonomi (internasional), orang menemukan negara yang terletak di persimpangan kebudayaan Jerman dan Latino itu mendapatkan pengaruh yang kuat dari kedua kebudayaan tersebut. ${ }^{19}$

Belakangan ini, EC-Law nampaknya "mendesak" Swis melakukan peleburan (amalgamating) tradisi hukumnya; melebur tradisi hukum Anglo-Saxon dan tradisi hukum Nordic. Secara unilateral, EC-Law dapat dikatakan "memaksa" Swis melakukan adopsi, dengan mendasarkan diri kepada prinsip yang dikenal dengan policies of eurocompatibility; meskipun secara formal, Swis bukanlah anggota dari Uni Eropa. "Pemaksaan" ini nampaknya dapat diterima di Swis, namun telah menimbulkan kecemasan dan reaksi yang keras dengan "Brexit" (British Exit) oleh Inggris. Dikawatirkan reaksi yang sama akan datang dari negara-negara yang mulai menyadari adanya ancaman kecemasan yang sama, ${ }^{20}$

Peleburan dapat dilihat dari perjanjian-perjanjian yang bersifat bilateral yang dibuat oleh Swis. Di dalam perjanjian-perjanjian itu dikatakan dapat ditemukan adanya import terhadap EC-Law. Alasan peleburan adalah persamaan (equivalence). Cara-cara melebur menggunakan apa yang disebut dengan static international agreements, yaitu perjanjian untuk menjaga kedaulatan yang bersifat formal dan kemerdekaan negara banggsa. ${ }^{21}$ Dengan begitu, EC-Law telah menjadi suatu titik rujukan dalam pembangunan hukum di Swis. Dalam peleburan atau harmonisasi itu ada hal-hal yang substansial hukum yang mengatur masyarakat Eropa diinternalisasi dalam sistem Swiss.

\section{Fungsi-Fungsi Ketatanegaraan dari Hukum Ekonomi}

Dalam rimba raya kaidah dan peraturan dari hukum ekonomi (internasional), beberapa fungsi kaidah hukum fundamental patut diperhatikan. Kaidah-kaidah dan asas-asas hukum mendasar itu diderivasi dari prinsip

${ }^{19} \mathrm{Hal}$ ini berbeda dengan pandangan dalam teori keadilan bermartabat yang meyakini bahwa hukum itu hanya dapat dijumpai dalam jiwa bangsa (Volksgeist), tidak dipengaruhi oleh budaya dari luar. Dalam teori keadilan bermartabat, yang tidak anti terhadap studi perbandingan, kalau ada unsur hukum dari negara luar maka hukum itu hanya menjadi jiwa bangsa kalau hukum dari luar itu telah disaring agar sesuai dengan nilai-nilai hukum sebagai jiwa suatu bangsa. Prinsip ini sama dengan regulatory competition yang dibahas dalam makalah ini, namun tidak terbatas pada kaidah tertentu saja, sebab teori keadilan bermartabat adalah suatu teori hukum, suatu filsafat hukum atau jurisprudence; the Indonesian Jurisprudence, Lihat Esin Orucu, The Enigma of Comparative Law: Variation on a Theme for the Twenty-First Century, First Published, Martinus Nijhoff, The Netherlands, 2004, hlm. 115.

\footnotetext{
${ }^{20}$ Ibid.

21 Ibid.
} 
persamaan. Prinsip persamaan pada hakikatnya adalah prinsip konstitusional, yang berkeadilan. Umumnya, dalam prinsip ini harus ada perlakuan yang sama dalam hal import misalnya yang diberikan satu negara kepada negara yang satu jika dibandingkan dengan perlakuan yang diberikan kepada negara yang lain.

Bagi WTO, prinsip persamaan sebagaimana maknanya sudah dikemukakan di atas melahirkan prinsip non-diskriminasi. Begitu pula prinsip tansparansi dan kemudahan memperoleh perlindungan hukum; semuanya bekerja untuk tercapainya syarat-syarat yang sama dalam persaingan, baik bagi bagi produk-produk asing maupun bagi produk-produk domestik. Prinsip ini jauh melampaui diskriminasi yang de facto maupun yang de jure. Misalnya yang berkenaan dengan ekolabel pedoman KAN 804.22

Pengaturan hukum WTO tentang proporsionalitas berlaku dalam melakukan penilaian pembatasan-pembatasan yang diberlakukan terhadap nondiskriminasi dalam rangka mengejar tujuan-tujuan kebijakan publik lainnya yang sah, khususnya kesehatan masyarakat (public) dan juga perlindungan terhadap lingkungan hidup. Dari berbagai varian pengaturan proporsionalitas yang ada, dapat dikemukakan di sinimisalnya masuknya International Standardisation Organisation (ISO), yang semula berasal dari Inggris.

Asas perlakuan khusus kepada negara atau bangsa yang paling disukai (most-favoured-nation), yaitu sebutan lain dari asas non-diskriminasi, berfungsi prinsip kepastian bahwa semua manfaat dan keuntungan, termasuk kelonggarankelonggaran dan fasilitas yang diberikan kepada satu pihak ketiga tertentu secara seketika dan tanpa syarat pula berlaku bagi semua anggota yang masuk dalam WTO. Hal itu diatur dalam Pasal 2 dari the General Agreement on Tariffs and Trade, misalnya ${ }^{23}$.

Prinsip most-favoured-nation, menurut penulis diadakan untuk memastikan persyaratan yang sama bagi semua produk yang sama dengan produk-produk yang diimport oleh suatu pasar tertentu. Mungkin saja ada pengecualianpengecualian yang sah terhadap hal itu, namun semuanya menurut penulis

\footnotetext{
${ }^{22}$ Soedjono Dirjosisworo, Kaidah-Kaidah Hukum Perdagangan Internasional (Perdagangan Multilateral) Versi Organisasi Perdagangan Dunia (World Trade Organization/WTO), Utomo, Bandung, 2004, hlm. 56.

${ }^{23}$ General Agreement on Tariff and Trade (GATT).
} 
haruslah memenuhi sejumlah kriteria yang diciptakan untuk mengurangi distorsi atau gangguan terhadap perdagangan. ${ }^{24}$

\section{Pemerintahan Multi-Tingkat dan Akibatnya bagi Kedaulatan Negara}

Asas atau prinsip non-diskriminasi dalam WTO Law adalah prinsip hukum yang sama dengan prinsip the Four Freedoms dalam EC-Law. Asas hukum itu berfungsi sebagai alat pengontrol bagi negara-negara nasional dan bagian-bagian dari negara Federal yang disebut dengan sub-federal levels. Menurut penulis, hal ini sama dengan atau Provinsi, Kabupaten/Kota di Indonesia. Ketika kontrol yang demikian itu terjadi, maka sejatinya suatu level pemerintahan menguat di tingkat Internasional. Hanya saja, dalam perspektif keadilan bermartabat, pemerintahan yang demikian itu harus bekerja dalam dan melalui penerapan prinsip-prinsip hukum yang telah dirumuskan di dalam konstitusi masingmasing negara berdaulat. Justifikasi terhadap hal ini, menurut penulis adalah persoalan jiwa bangsa.

Pemerintahan di tingkat internasional itu melakukan ajudikasi atau pengadilan dan penyelesaian sengketa. Begitu pula Pemerintahan itu memilki kewenangan untuk menegakkan hak-hak melalui penjatuhan sanksi-sanksi perdagangan dan pembatalan terhadap hak-hak untuk memperoleh akses berdagang di pasar yang dilakukan oleh pihak yang melanggar. Meskipun di tingkat internasional, pemerintahan itu juga bekerja membuat peraturan perundang-undangan (legislative works), yang dilakukan di dalam dan dengan cara melakukan negosiasi-negosiasi berbasis traktat. Berbagai aturan dibuat sebagai elaborasi lebih lanjut atas prinsip non-diskriminasi dan transparansi di WTO Law, begitu pula the Four Freedom di EC Law. Kewenangan pemerintahan (proses politik) yang melahirkan kaidah-kaidah karena adanya kewenangan yang didelegasikan oleh masing-masing anggota, dengan jalan perjanjian internasional.

Proses politik memiliki kecenderungan untuk mengabaikan atau mengesampingkan kepentingan-kepentingan yang berkenaan dengan produkproduk import. Hal ini terjadi karena pihak-pihak importir memang tidak terwakili atau kurang terwakili dalam proses politik pengambilan keputusan di

${ }^{24}$ Sordjono Dirjosisworo, Kaidah-Kaidah Hukum Perdagangan Internasional...., Op. Cit., hlm. 76. 
dalam negeri (domestik). Tambahan pula, proses politik domestik seringkali bekerja di bawah kendali prinsip pemerintahan berdasarkan suara terbanyak (majority rule), atau suatu kekuasaan pemerintah eksekutif yang kuat.

Sementara itu, kecemasan muncul mengingat the Lock-In effect dari asas-asas hukum, baik yang ada dalam WTO Law maupun EC Law mengikat atau mengunci Pemerintah domestik untuk mematuhi komitment yang telah dibuat. Oleh sebab itu asas-asas tersebut berhasil menciptakan pagar agar tidak dimasuki oleh tuntutan-tuntutan yang mendasarkan diri kepada keinginan untuk mendapatkan perlindungan, dari mereka yang disebut dengan protectionist; politisi domestik. Menurut penulis, dari sudut pandang hukum tata negara, fungsi yang ada dari asas-asas hukum di atas, nampak sama dengan hak-hak konstitusional yang juga berfungsi sebagai alat kontrol tidak hanya untuk legislasi di tingkat nasional, namun juga atas tindakan-tindakan yang diambil di tingkat sub-federal, dan dalam negara kesatuan seperti Republik Indonesia disebut dengan tingkat provinsi dan kabupaten/kota.

Sama halnya dengan prinsip-prinsip dalam konstitusi itu, maka prinsipprinsip hukum ekonomi di tingkat internasional itu mengunci (lock-in) tingkat pemerintahan domestik tersebut dan menciptakan keseimbangan antara hukum dan peraturan perundang-undangan serta kebijakan publik yang tercipta atas dasar pemerintahan mayoritas di tingkat nasional maupun di tingkat provinsi, kabupaten, dan kota yang melanggar hak-hak konstitusional dimaksud.

Penting sekali karena itu untuk mengakui fungsi pemberian ganti kerugian yang terdapat di dalam kaidah maupun asas-asas yang diatur oleh WTO. Semuanya adalah manifestasi paling konkret dan jelas dari negara hukum, yaitu prinsip yang di dalam teori keadilan bermartabat disebut sebagai jiwa bangsa Indonesia (Volksgeist), derivasi dari Pancasila, sumber dari segala sumber hukum, yang memberikan perlindungan kepada harapan-harapan manusia sebagai makhluk ciptaan Tuhan Yang Maha Esa yang mulia, yang beraktivitas dalam bidang ekonomi dan perdagangan, baik nasional maupun internasional. Asasasas hukum itu digunakan dengan cara membelah kekuasaan politik di antara tingkat-tingkat tempat tindakan dilakukan dan di antara pelaku yang berbeda- 
beda. Pada titik ini dapat dikatakan bahwa kaidah-kaidah dan asas-asas Hukum Ekonomi itu menyediakan sarana berupa checks and balances untuk jajaran di tingkat vertical. ${ }^{25}$

Dengan melakukan hal itu maka prinsip-prinsip itu menyediakan atau memberikan sumbangan bagi legitimasi yang bersifat menyeluruh, sekalipun pada akhirnya prinsip-prinsip itu mungkin saja memotong keputusan-keputusan yang dihasilkan oleh suatu pemerintahan mayoritas; dan sekalipun tampak seolah-olah apa yang dilakukan itu bertentangan dengan demokrasi sebagai suatu etika politik. Sehingga orang mengatakan bahwa prinsip-prinsip itu merupakan benda publik yang keberadaannya sangat penting dan kritikal dalam hukum.

Sudah merupakan pandangan umum, bahwa ada sementara pihak masih berpikir bahwa menyamakan hukum nasional dengan hukum internasional dalam kaitannya dengan hukum tata negara (constitutional law) merupakan hal yang sangat kontroversial; mengancam kedaulatan negara-ngara. Mengingat banyak ahli hukum tata negara bersikeras bahwa hukum tata negara itu hanya untuk hukum nasional, suatu tuntutan atau persyaratan bagi adanya atau terbentuknya suatu masyarakat yang homogen. ${ }^{26}$

Umumnya orang berpendapat bahwa hukum tata negara tidak dapat diperluas hingga mencakup hukum internasional. Begitu pula pendapat bahwa hukum tata negara tidak dapat diperluas ke lingkup masyarakat yang sangat terfragmentasi dan menjadi suatu nilai dan kebudayaan bersama di dalam hukum. Hal itu tidak terjadi di Indonesia, dengan tingkat pluralisme yang sangat tinggi. Mungkin karena kenyataan yang demikian itulah, telah menyebabkan WTO sering sekali ditentang dengan bangunan argumentasi yang didasarkan kepada demokrasi sebagai legitimasi dari berbagai ketentuan atau kaidah Hukum Ekonomi itu. 27

${ }^{25}$ Anne Peters, The Globalization of State Constitutions, in Jane Nijman and Andre Nollkaemper, New Perspectives on the Divide Between National and International Law, Oxford University Press, Oxford, 2007, hlm. 251308.

${ }^{26}$ Cavendish L. C., Constitutional Law, Reprinted, Cavendish Publishing Ltd., 1998, p. 4.

${ }^{27}$ Lihat, Manfred Elsig, "The World Trade Organization's Legitimacy Crisis: What Does the Beast Look Like?", 41stJournal of World Trade, 2007, hlm. 75-98; Daniel Esty, “The World Trade Organization's Legitimacy Crisis", 1st World Trade Review, 2002, hlm. 7-22; Markus Krajewski, "Democratic Legitimacy and Constitutional Perspective 
Telah dikemukakan bahwa suatu proses diplomatik, yang diikuti dalam pembuatan peraturan perundangan dan bahkan harmonisasi hukum tidak cukup melibatkan banyak kalangan yang luas dan terencana secara baik dalam kaitannya dengan para pemangku kepentingan stakeholders, ${ }^{28}$ secara khusus pihak dimaksud, yaitu organisasi-organisasi non-pemerintahan (LSM atau NGO) yang memperjuangkan dan mempertahankan keberadaan kepentinan global. Kelemahan dari demokrasi yang sama dengan yang dikemukakan di atas, juga sering didengungkan dalam kaitannya ketika orang berbicara mengenai Uni Eropa. ${ }^{29}$

Terdapat secara inheren legitimasi yuridis dan dengan demikian tidak dibutuhkan sebetulnya dukungan yang bersifat tambahan, misalnya dengan jalan proses yang bersifat demokratis dari pengambilan keputusan. ${ }^{30}$ Kenyataan menujukkan, bahwa kebanyakan dari putusan-putusan yang dihasilkan harus diambil-alih dan dilaksanakan oleh Pemerintah di masing-masing negara. ${ }^{31}$

Inilah arti penting kebutuhan akan adanya pemahaman atau makna kedaulatan negara yang baru dalam hukum ekonomi (internasional). ${ }^{32}$ Dari sudut teori keadilan bermartabat sebagai sautu teori hukum murni, dapat dikatakan dengan tegas bahwa kedaulatan negara-negara tidaklah terpengaruh, sebab setiap negara berdaulat itu toch memberikan persetujuan sebelum kaidah-kaidah dan asas-asas hukum itu diaplikasikan dan ditegakkan. hukum ekonomi (internasional) juga memperbesar peranan dari Pengadilan dan Hakim. Keengganan tradisional yang ada para para hakim untuk berurusan dengan soalsoal asing dan kebiasaan yang selama ini mereka menyerahkan saja kepada

of WTO Law", 35th Journal of World Trade,2001, hlm. 167-168; Eric Stein, International Integration and Democracy: No Love at First Sight, 95/3 American Journal of International Law, 2001, hlm. 489-534.

${ }^{28}$ Orang-orang yang terlibat dalam sistem yang ada yang memiliki kepentingan karena mereka juga telah ikut berkontrubusi bagi keberadaan sistem atau organisasi yang ada.

${ }^{29}$ Andreas Follesdal and Simon Hix, "Why there is a Democratic Deficit in the European Union A Response toMAjone and Moravscsik", dalam European Governance Papers No. C-05-02 (2005), dapat dilihat dalam http://www.connex.network.org/eurogov/pdf/egp-connex-C-05-02.pdf; Christophe Crombez, "The Democratic Devisit in European Union: Much Ado About Nothing?”, dalam European Union Politics, 2003, hlm. $101-120$

${ }^{30}$ Stephan Breitenmoser, dkk (eds), Human Rights, Democracy and the Rule of Law: Liber Amicorum Luzius Wildhaber, Zürich/Baden-Baden. Dike, 2007,hlm. 551-593.

${ }^{31}$ William J. Davey, "The WTO Dispute Settlement System: The First Ten Years", dalam 8 Journal of International Economic Law, 2005, hlm. 17-50.

${ }^{32} \mathrm{John}$ H. Jackson, Sovereignty, the WTO and Changing Fundamentals of International Law, Cambridge University Press, Cambridge, 2006, hlm. 1. 
cabang kekuasaan eksekutif karena hal itu merupakan soal hubungan internasional, kini sudah mulai ditinggalkan.

\section{Penutup}

Memperhatikan gambaran hasil penelitian dan pembahasan di atas maka jawaban atas rumusan permasalahan bagaimana hakikat atau profil hukum ekonomi (internasional) dalam perspektif Keadilan Bermartabat dapat disimpulkan sebagai berikut. Penelitian menemukan bahwa yang dimaksud dengan hakikat, profil atau "wajah" dari hukum ekonomi (internasional) itu pada dasarnya adalah hukum dari luar yurisdiksi negara berdaulat yang diadopsi ke dalam sistem hukum nasional dalam rangka mengatur kegiatan perekonomian nasional maupun Internasional yang dilakukan oleh suatu negara.

Berbagai asas dan kaidah hukum ekonomi (internasional) adalah merupakan asas-asas dan kaidah hukum yang juga pada hakikatnya adalah merupakan asas-asas dan kaidah dalam sistem hukum masing-masing negara berdaulat. Sehingga profil atau "wajah" hukum ekonomi (tnternasional) bukan merupakan "wajah" asing yang perlu ditakuti hukum nasional. Lebih-lebih lagi, dalam perspektif teori keadilan bermartabat, di Indonesia keberadaan dari hukum ekonomi (internasional) dalam hukum nasional melaui penyaringan dengan nilai-nilai dalam Pancasila (Volksgeist Indonesia). Dalam hal itu, tidak perlu ada kekhawatiran dan kecemasan di balik pertumbuhan hukum ekonomi (internasional) bakal mengancam kedaulatan negara, dan demokrasi. Meskipun setiap ancaman terhadap kedaulatan harus selalu diwaspadai.

Hukum ekonomi (internasional) itu sedang bertumbuh dan juga meluaskan pengaruhnya dalam dekade belakangan ini mempengaruhi struktur konstitusional masing-masing negara. Dinamika dari hukum ekonomi (internasional), mengatur dan menuntun kebutuhan ekonomi internasional dan global, telah menyebabkan masyarakat atau rakyat dalam semua bangsa berdaulat, termasuk Indonesia harus bekerja menghadapi tantangan-tantangan struktural, yang dibawa oleh hukum ekonomi (internasional). Dengan instrumen ratifikasi, suatu negara nasional seperti Indonesia tidak perlu harus merasa kuatir 
yang berlebihan bahwa hukum ekonomi (internasional) akan mengancam kedaulatan hukum dari negara berdaulat dan juga demokrasi.

Ratifikasi adalah suatu alat yang dapat dipergunakan dalam rangka melakukan penyaringan terhadap asas-asas dan kaidah dalam hukum internasional yang tidak sesuai dengan Volksgeist Indonesia. Ratifikasi dapat menjadi alat dalam jiwa bangsa untuk menyaring masuknya hukum ekonomi (internasional) yang tiak sesuai dengan kebutuhan dan dapat merusak nilai-nilai hukum nasional.

Dalam melakukan penyaringan dengan menggunakan instrumen ratifikasi, disarankan agar pengaturan atau hukum ekonomi (internasional) yang akan diratifikasi dipastikan akan menjadi sarana yang membantu mendatangkan suatu distribusi kemakmuran yang lebih adil di dalam masing-masing negara nasional, dan juga mendatangkan Keadilan Bermartabat, yaitu Keadilan yang memanusiakan manusia. Dengan kata lain, bagi Indonesia hukum ekonomi (internasional) perlu dikembangkan dengan memperhatikan nilai-nilai dalam Pancasila, sebelum hal itu diratifikasi dan diimplementasikan.

\section{Daftar Pustaka}

\section{Buku}

Breitenmoser, Stephan, et. al (eds), Human Rights, Democracy and the Rule of Law: Liber Amicorum Luzius Wildhaber, Zürich/Baden-Baden, Dike, 2007.

Crombez, Christophe, The Democratic Devisit in European Union: Much Ado About Nothing?, European Union Politics, 2003.

Dirjosisworo, Soedjono, Kaidah-Kaidah Hukum Perdagangan Internasional (Perdagangan Multilateral) Versi Organisasi Perdagangan Dunia (World Trade Organization/WTO), Utomo, Bandung, 2004.

Goode, Roy, Commercial Law, New Edition, Penguin Books, England, 1995.

Jackson, John H., Sovereignty, the WTO and Changing Fundamentals of International Law, Cambridge, Cambridge University Press, 2006.

Kadar, Abby, Ken Houle \& Geoffrey Whitehead, Business Law, $4^{\text {th }}$ Edition, Butterworth-Heinemann Ltd., Oxford, 1996.

L. C., Cavendish, Constitutional Law, Reprinted, Cavendish Publishing Ltd., 1998.

Orucu, Esin, The Enigma of Comparative Law: Variations on a Theme for the TwentyFirst Century, First Printed, Martinus Nijhoff Publishers, the Netherlands, 2004. 
Peters, Anne, The Globalization of State Constitutions, in Jane Nijman and Andre Nollkaemper, New Perspectives on the Divide Between National and International Law, Oxford, Oxford University Press, 2007.

Prasetyo, Teguh dan Abdul Halim Barkatullah, Filsafat, Teori, \& Ilmu Hukum: Pemikiran Menuju Masyarakat yang Berkeadilan dan Bermartabat, Cetakan I, RajaGrafindo Persada, Depok, 2012.

Prasetyo, Teguh, Keadilan Bermartabat: Perspektif Teori Hukum, Cetakan Pertama, Nusamedia, Bandung, 2015.

Pembaharuan Hukum: Perspektif Teori Keadilan Bermartabat, Cetakan Pertama, Setara Press, Malang, 2017.

Penelitian Hukum: Suatu Perspektif Teori Keadilan Bermartabat, Cetakan ke-1, Nusa Media, Bandung, 2019.

Rawls, John, A Theory of Justice (Revised Edition), Harvard University Press, USA, 1999.

\section{Jurnal}

Davey, William J., The WTO Dispute Settlement System: The First Ten Years, Journal of International Economic Law, Vol., 8, 2005.

Elsig, Manfred, The World Trade Organization's Legitimacy Crisis: What Does the Beast Look Like?, Journal of World Trade, Vol. 41, 2007.

Esty. Daniel, The World Trade Organization's Legitimacy Crisis, World Trade Review, Vol. 1, 2002;

I Gusti Ayu Ketut Rachmi Handayani, et. al., The Application of Article 359 of the Criminal Code in the Investigation of the Death of Post-Operative Patients, Asers Publishing, September, 2017,Vol VIII, Issue 5, 2017.

Krajewski, Markus, Democratic Legitimacy and Constitutional Perspective of WTO Law, Journal of World Trade, Vol. 35, 2001.

Stein. Eric, International Integration and Democracy: No Love at First Sight, American Journal of International Law, Vol. 3, 2001.

Teguh Prasetyo and Tri Astuti Handayani, Legal Aid Principle: (Dignified Justice Theory Perspective), International Journal of Advanced Research (IJAR), Vol.1, 2016.

Teguh Prasetyo, Pancasila the Ultimate of All the Sources of Laws (A Dignified Justice Perspective), Journal of Law, Policy and Globalization, International Institute for Science, Technology and Education (IISTE), Vol. 54, 2016.

Criminal Liability of Doctor in Indonesia (From A Dignified Justice Perspective), International Journal of Advanced Research (IJAR), 1(10);

Shallman, TeguhPrasetyo and Amin Purnawan, Public Service on Land Registration Based on the Dignified Justice, Journal of Advanced Research (IJAR), Int. J. Adv. Res. Vol. 5, 2016. 


\section{Peraturan Perundang-Undangan}

Undang-Undang Republik Indonesia Nomor 7 Tahun 1994 tentang Pengesahan Agreement Establishing the World Trade Organization (Persetujuan Pembentukan Organisasi Perdagangan Dunia).

Undang-Undang Republik Indonesia Nomor 24 Tahun 2000 tentang Perjanjian Internasional. 